\title{
SHAREHOLDER POWER AS AN ACCOUNTABILITY MECHANISM: THE 2017 SHAREHOLDER RIGHTS DIRECTIVE AND THE CHALLENGES TOWARDS ENHANCING SHAREHOLDER RIGHTS
}

\author{
Rafael Savva*
}

\begin{abstract}
The 2017 Shareholder Rights Directive has paved the way towards adopting a model where shareholder power can be used as an accountability mechanism in European corporate governance by amending the 2007 Shareholder Rights Directive to encourage active shareholder participation. This model can ensure good governance practices, but practical implications can challenge its effectiveness. This paper seeks to outline the merits and the challenges this model must overcome to be effective. The Directive manifests EU corporate law's adoption of a model where shareholders power is used to confer accountability in corporate governance. Despite the model's merits, there are implications that may impede its effectiveness. Firstly, several problems related to agency capitalism and the establishment of collective action, such as participation costs, disclosure of information; free-riding and incentives of exercising shareholder rights can significantly affect proper shareholder engagement. Secondly, another implication is found on shareholder short-termism and the basis on which shareholder power is to be exercised to confer accountability. Though the Directive addresses these issues to some extent, the appropriate consideration of all issues of these implications is paramount. As such, the Directive is only the starting point towards the facilitation of shareholder power act as an accountability mechanism.
\end{abstract}

KEYWORDS: European Corporate Law, Corporate Governance, Shareholder Rights, Shareholder Power, Accountability

\footnotetext{
PhD Candidate/Associate Lecturer, Lancaster University; r.savva1@lancaster.ac.uk
} 


\section{INTRODUCTION}

The 2008 financial crisis highlighted serious flaws in corporate governance and accountability and has questioned the extent European and National corporate governance regulation was adequate to prevent these misconducts. As a reaction to the economic crisis, legal regulators reiterated a long-standing position of the European Union that shareholders must play a more responsible role in upholding accountability in corporate governance. ${ }^{1}$ This led to the introduction of the 2017 Shareholder Rights Directive. ${ }^{2}$ The 2017 Directive seeks to amend the 2007 Shareholder Rights Directive ${ }^{3}$ in order to strengthen shareholder monitoring; enhance transparency between companies and its investors and encourage active shareholder engagement for the long-term benefit of the company. ${ }^{4}$ In line then with an international upsurge in enhancing shareholder rights, European corporate law through the 2017 Shareholder Rights Directive paves the way towards adopting a corporate governance model where shareholders act as an accountability body in corporate governance to prevent managerial inefficiencies through the exercise of their respective rights.

This model of corporate governance has undoubtedly its merits. An effective shareholder engagement is cornerstone to upholding good corporate governance; and can enhance the checks and balances between different organs of the company. ${ }^{5}$ Furthermore, the active exercise of shareholder rights can improve corporate performance, by taking into account issues related to the company's stakeholders or upholding public interest. ${ }^{6}$ Despite the merits of this model however, several implications can impede the exercise of shareholder power as an effective accountability mechanism; and can challenge the mod-

Communication From The Commission To The European Parliament, The Council, The European Economic And Social Committee And The Committee Of The Regions: Action Plan: European company law and corporate governance - a modern legal framework for more engaged shareholders and sustainable companies (COM/2012/0740, 2012)

2 Directive (EU) 2017/828 of the European Parliament and of the Council of 17 May 2017 amending Directive 2007/36/EC as regards the encouragement of long-term shareholder engagement (Shareholder Rights Directive 2017) (OJ L 132, 20.5.2017)

3 Directive 2007/36/EC of the European Parliament and of the Council of 11 July 2007 on the exercise of certain rights of shareholders in listed companies (Shareholder Rights Directive 2007) (OJ L 184, 14.7.2007)

4 Shareholder Rights Directive 2017, [3]

5 ibid [14]

6 On stakeholder considerations in the company see Parkinson, J.E.: Corporate Power and Responsibility: Issues in the Theory of Company Law, Oxford/ Oxford University Press, 2002; Dodd E. M.: For whom are corporate managers trustees, Harvard Law Review, 45 1932, p. 1145 
el's adequateness and effectiveness for securing good corporate governance practices for the company's sustainable growth.

This paper then seeks to highlight the merits of the model the 2017 Shareholder Rights Directive seeks to introduce, as well as the challenges that European corporate law must address to ensure its effectiveness. Section 2 will state that the 2017 Shareholder Rights Directive contributes in the adoption of a corporate governance model where shareholders exercise their power to enhance accountability. Sections 3 and 4 will highlight several implications that can impede the model's effectiveness should they are not addressed effectively. Section 3 will argue that implications arising from the director-shareholder agency problem that are related to the establishment of collective action and the practice of agency capitalism may affect shareholder power to confer accountability effectively. Though the Directive deals to some extent with these issues; the challenges arising because of the costs of participation, free-riding, information quality and intermediary incentives to exercise shareholder rights need to be addressed more effectively. Section 4 will argue that another implication is found on the basis on which shareholder power is to be exercised. This is because shareholder power may be abused as a means of securing abnormal short-term returns. The security then of a corporate objective that ensures that shareholder power is exercised for conferring accountability for the company's sustainable growth is paramount. Section 5 will conclude that the 2017 Shareholder Rights Directive is only the starting point towards the facilitation of a model where shareholders act as an accountability body. As such, European company law should take these practical implications into account as well to ensure the model's effectiveness.

\section{THE 2017 SHAREHOLDER RIGHTS DIRECTIVE: TOWARDS ADOPTING A DEVELOPING MODEL FOR CORPORATE GOVERNANCE}

The 2017 Shareholder Rights Directive seeks to amend the 2007 Shareholder Rights Directive and encourage more active shareholder engagement to enhance accountability in corporate governance. The first of the changes regard the enhancement of shareholder voting power. The Directive acknowledges that directors' remuneration should contribute to the company's advancement of accountability to achieve sustainability in corporate governance using performance criteria related both to financial and stakeholder factors. ${ }^{7}$ In light of this, Article 9a of the 2007 Directive will state that Member States will en-

Shareholder Rights Directive 2017, [35] 
sure that companies will establish a remuneration policy for its directors that will be subject to shareholder approval. ${ }^{8}$ However, Member States may provide rules for the vote to be advisory; on which case remuneration will be paid to directors only in accordance with a remuneration policy that has been submitted for shareholder consideration. ${ }^{9}$ In addition to that, the 2017 Directive seeks to enhance accountability for a number of transactions that may cause prejudice to the company. ${ }^{10}$ Article $9 \mathrm{c}$ of the 2007 Directive then will require Member States to ensure that companies will publicly announce a number of key related-party transactions, which shall be subject to shareholder approval or to an approval by the administrative or the supervisory body of the company. ${ }^{11}$

The 2017 Directive further seeks to contribute to the enhancement of transparency between the company and its respective shareholders. The identification of shareholders then becomes a prerequisite to facilitate communication between shareholders and the company to encourage better shareholder engagement. ${ }^{12}$ Based on this premise, Article 3a of the 2007 Directive will state that Member States will ensure that national corporate law will allow companies to identify its respective shareholders, ${ }^{13}$ and establish a requirement for shareholder intermediaries to contribute towards such identification, ${ }^{14}$ subject to compliance with all necessary data protection legislation. ${ }^{15}$ Furthermore, the 2007 Directive will compel such identification when the shareholding percentage exceeds $0,5 \%$ of the company's shareholding. ${ }^{16}$ In addition to the identification requirements, the 2017 Directive seeks to enhance transparency by implementing rules for the effective transmission of information between companies and shareholders. Article $3 b$ then seeks to achieve this by requiring Member States to ensure that shareholder intermediaries are required to trans-

\footnotetext{
8 Shareholder Rights Directive 2007 (as amended by the Shareholder Rights Directive 2017), Art. 9a

9 ibid

10 Shareholder Rights Directive 2017, [45]

11 Shareholder Rights Directive 2007 (as amended by the Shareholder Rights Directive 2017), Art. 9c

12 Shareholder Rights Directive 2017, [4]-[6]

13 Shareholder Rights Directive 2007 (as amended by the Shareholder Rights Directive 2017), Art. 3a

14 ibid

15 Regulation (EU) 2016/679 of the European Parliament and of the Council of 27 April 2016 on the protection of natural persons with regard to the processing of personal data and on the free movement of such data, and repealing Directive 95/46/EC (OJ L 119, 4.5.2016)

16 Shareholder Rights Directive 2007 (as amended by the Shareholder Rights Directive 2017), Art. 3a (1)
} 
mit all necessary information required for the shareholder to be able to exercise its rights effectively; or give notice of the availability of such information in case they are available online. ${ }^{17}$

In addition, the 2017 Directive acknowledges that the active exercise of shareholder power by institutional shareholders and shareholder intermediaries is significant to facilitate accountability for corporate governance. ${ }^{18}$ The importance of the existence of such intermediaries and institutional shareholders is undoubted. Institutional shareholders and intermediaries can reduce significantly issues related to the inability of shareholders to exercise their power efficiently as a result of the wide dispersion in shareholding ownership that was noted in public corporations. ${ }^{19}$ Furthermore, shareholder intermediaries and institutional shareholders can utilise their expertise to actively exercise shareholding rights. In light of this, Article 3c of the 2007 Directive will state that all intermediaries and institutional investors' asset managers will engage with exercising shareholder rights. ${ }^{20}$

In addition, Article 3g will impose an obligation on institutional shareholders to disclose their engagement policy on a comply-or-explain basis; which will entail details related to the monitoring of the investee company or outline the engagement of shareholder rights for relevant matters including investment strategy and the corporate financial performance and risk. ${ }^{21}$ Article $3 \mathrm{i}$ of the 2007 Directive will require asset managers to disclose on an annual basis the means the investment strategy is being implemented for the medium to long-

\footnotetext{
17 Shareholder Rights Directive 2007 (as amended by the Shareholder Rights Directive 2017), Art. 3b

18 Shareholder Rights Directive 2017, [9], [14], [15]

19 Mallin C.: Institutional investors: the vote as a tool of governance, Journal of Management Governance, 16 2012, p.180; Gillan, S. L., Starks, L.T.: Corporate Governance Proposals and Shareholder Activism: The Role of Institutional Investors, Journal of Finance and Economics, 57 2000, pp. 278-79; Rose, P.: The Corporate Governance Industry, Journal of Corporate Law, 32 2007, p. 887. On the history of the dispersion of shareholding ownership in the US and Europe see in general Morck R. (ed): A History of Corporate Governance Around the World: Family Business Groups to Professional Managers, University of Chicago Press, 2007; Wells, H.: A Long View Of Shareholder Power: From The Antebellum Corporation To The Twenty-First Century, Florida Law Review, 67 2015; Berle A.A; Means, G.G.: The Modern Corporation and Private Property, revised ed., New Jersey, 1991; Davies, P.: Shareholders in the United Kingdom in Hill, J.G. and Thomas, R.S. (eds.): Research Handbook on Shareholder Power, Cheltenham, 2015; Cheffins, B. R.: Law as Bedrock: The Foundations of an Economy Dominated by Widely Held Public Companies, Oxford Journal of Legal Studies, 232003

20 Shareholder Rights Directive 2007 (as amended by the Shareholder Rights Directive 2017), Art. 3c

$21 \quad$ ibid Art.3g
} 
term performance of the assets of the institutional investor, which will include, among other information, how the investment strategy will affect the medium to long-term financial and non-financial performance of the company. ${ }^{22}$ Moreover, Member States under Article 3j will be responsible for ensuring that proxy advisors will apply, on a comply-or-explain basis, a code of conduct which shall be disclosed to shareholders; and are required to publicly disclose on an annual basis how they are undertaking their duties for shareholders with regards to the preparation of research, advice and voting recommendations. ${ }^{23}$ Moreover, to facilitate further engagement, the 2007 Directive will further require Member States to ensure that there is no discrimination in the incurrence of costs for shareholders on cross-border voting, unless justified where such costs will reflect the variation of actual costs on the implementation or provision of the services as a means of mitigating costs and encourage further engagement. $^{24}$

The 2017 Directive manifests the EU regulators' attempts to conform with an international set of thinking in corporate governance that seeks to adopt a corporate governance model where shareholders exercise their power to provide accountability in corporate governance. The emergence of this idea is not new. The beginning of the $21^{\text {st }}$ century came with the emergence of several corporate scandals, both in the US and Europe ${ }^{25}$ that led to the reconsideration of the prevailing model of absolute managerial control; and the suggestion of more active shareholder participation to counter managerial indiscretion. ${ }^{26}$ Based on this model, shareholders can utilise their power to improve the decision-making process through monitoring the executive management for the long-term interests of the company. This model sees shareholders as being more responsible for the affairs of the company, whose active exercise of their rights will mitigate corporate inefficiencies by signalling managerial irregularities or malperformance. ${ }^{27}$ Shareholders then with their expertise and power will have a responsibility towards the company they invested in to keep

\footnotetext{
22 ibid Art.3i

23 ibid Art. 3j

24 ibid Art 3d

25 See in general Fox, L.: Enron: Rise and Fall, Hoboken, 2003; Bava, F.; Devalle, A.: Corporate governance and best practices: the Parmalat case, GSTF Business Review, 2 2012; Eriksson, K.: Corporate Governance in the European Union post-Enron, Business Law Review, 15 2003.

26 ibid; see also Armour, J. et al.: Shareholder Primacy and the Trajectory of UK Corporate Governance, British Journal of Industrial Relations, 41 2003, p.542

27 Bebchuck, L. B.: The Case for Increasing Shareholder Power, Harvard Law Review, 118 2005, p. 892
} 
the management accountable. It must be noted that this model does not seek to inhibit the ability of the management to take decisions. On the contrary, this model seeks to provide the ability to shareholders to raise their concerns and pursuit changes only when the management's actions affect the company adversely. ${ }^{28}$ On this premise then, shareholder power enables certain questionable managerial actions to be subject to shareholder consent or control to ensure that responsible governance is at all times upheld.

The merits of this model are numerous. An effective shareholder engagement is cornerstone to upholding good corporate governance; and can enhance the checks and balances between the different organs of the company. ${ }^{29}$ This is because shareholders, through the exercise of their rights, can contribute to the advancement of accountability in corporate governance by using of their rights to monitor questionable managerial actions or actions that may significantly deter corporate performance. In this way, shareholders can significantly counter managerial opportunism or inefficient performance; ${ }^{30}$ and thus act as a corrective mechanism in corporate governance which contributes to the enhancement of accountability internally. ${ }^{31}$ Furthermore, the active exercise of shareholder rights can improve corporate performance, by taking as well into account issues related to the company's stakeholders and its responsibility towards the society in general. ${ }^{32}$ Shareholder power then can be used not only for the furtherance of shareholder interests, but also for furthering the company's sustainable growth, which will secure their interests as well through the pursuit of good corporate governance. The combination of both will further contribute to the efficient operation of European capital markets; which will increase confidence in the undertaking of cross-border business that will enhance both the Internal Market and the national economies of European Member States as well. An effective exercise then of shareholder rights as an accountability mechanism will enable shareholders to assess the company's relative performance and sustainable growth. ${ }^{33}$

28 Hill, J.: Visions and Revisions of the Shareholder, The American Journal of Comparative Law, 48 2000, p.60

29 Fama, E.F.; Jensen, M.C.: Separation of Ownership and Control, Journal of Law and Economics, 26 1983, pp. 301-310

30 Moore, M.; Petrin, M.: Corporate Governance: Law, Regulation and Theory, London, 2017, pp. 90-93

31 ibid

32 ibid

33 On the meaning of sustainable growth for a company see Keay, A.: The Corporate Objective, Cheltenham, 2011 
Nevertheless, the efforts made for the adoption of this model via the 2017 Directive bear a number of material implications that need to be addressed by European and national corporate law more effectively to ensure that shareholders will actually contribute to the enhancement of accountability in corporate governance under this model.

\section{THE MULTIDIMENSIONAL SHAREHOLDER-DIRECTOR AGENCY PROBLEM: COLLECTIVE ACTION AND AGENCY CAPITALISM}

The multidimensional shareholder-director agency problem creates a number of practical implications that can impede the effectiveness of shareholder power as an accountability mechanism should they are not addressed effectively by corporate governance regulation to facilitate such a model for corporate governance. When the management falls short of their responsibility to secure the company's sustainable coverage of its liabilities, ${ }^{34}$ the need for shareholder monitoring generates a number of agency costs. ${ }^{35}$ In theory, the single owner of all shareholding of a company will try to keep the management accountable regardless of the costs, as the sustainable running of the company is of paramount concern to the sole shareholder. ${ }^{36}$ In the context of public companies though, the costs of keeping directors accountable may exceed the advantage shareholders will have to keep directors accountable, thus making them dis-interested or unable to monitor directors by themselves. ${ }^{37}$ For this reason, shareholders are required to undertake a collective action as a means to mitigate agency costs incurred from the need to keep the management accountable.

Collective action though poses a number of additional agency problems, ${ }^{38}$ as additional costs are required to be incurred to co-ordinate shareholder incen-

\footnotetext{
34 Bainbridge, S. M.: Why a Board? Group Decisionmaking in Corporate Governance, Vanderbilt Law Review, 55 2002, p.10

35 Fama, E.G.; Jensen, M.C.; Agency Problems and Residual Claims, The Journal of Law \& Economics, 26 (2) 1983, pp. 330-334

36 ibid

37 Black, B.S.: Shareholder Passivity Re-examined, Michigan Law Review, 89 1990, p. 566. Corporate Governance systems with an administrative body or supervisory board bear additional agency problems and costs as a result of the need to co-ordinate the administrative body or supervisory board to correct managerial inefficiencies. For the dimension of such problems in Germany see in general Schulz, M.; Wasmeier, O.: The Law of Business Organizations: A Concise Overview of German Corporate Law, Berlin, 2012, pp. 40-53; du Plessis, J. et al:: German Corporate Governance in International and European Context (2nd edn), Berlin, 2012, p. 159

38 Rock, E.B.: The Logic and (Uncertain) Significance of Institutional Shareholder Activism, The Georgetown Law Journal, 79 1990, p. 453
} 
tives and ensure the action's success. ${ }^{39}$ The incentives of shareholders then to engage in a collective action become material. The traditional logic behind shareholder collective action typically sees shareholders finding it difficult to engage in a collective action. This idea is attributed to Olson's fundamental work, the "Logic of Collective Action". ${ }^{40}$ To Olson, individuals in a large group driven by their self-interest and economic rationality will typically engage in a collective action only when the advantage provided from the collective action is greater than the costs incurred to undertake such a collective action. ${ }^{41}$ Thus, any group to which the advantage conferred on each individual is outweighed by the costs or the advantage conferred is zero will be latent. For Olson though, individuals of a large group will find it difficult to engage in a collective action given the group's size; and will thus be latent. ${ }^{42}$ This is because individuals in a large group may find it difficult or less rational to engage in a collective action with each abstention of an individual from the collective action. The amount of the advantage conferred to each shareholder will be minimised with each abstention of a shareholder, as fewer members will have to bear the costs of the collective action, and thus be less rational for the bearers of the cost to engage as the advantage for them will be continuously minimised. ${ }^{43}$

The traditional idea of collective action problems reflects a fraction of the practical implications shareholders face when there is a need to take a collective action to exercise their rights. A shareholder who is primarily incentivised by its own self-interest or engage in a collective action based on what is considered economically rational may engage in a collective action when it determines that managerial accountability will confer significant advantages, especially if the action will be engaged by a good number of shareholders that can reduce agency costs incurred per individual shareholder. ${ }^{44}$ Based on Olson's understanding though, shareholders may not find collective action to be in their best interests, ${ }^{45}$ since the need for a collective action in a large group of shareholders makes co-ordination of interests difficult. ${ }^{46}$

\footnotetext{
39 ibid

40 Olson, M.: The Logic of Collective Action, London, 1971

$41 \quad$ Ibid pp. 37; 61-63; 174

42 Ibid p. 48

$43 \quad$ Ibid p. 53

44 Sharfman, B.S.: Activist Hedge Funds In A World Of Board Independence: Creators Or Destroyers Of Long-Term Value?, Columbia Business Law Review, 2015, pp. 824-825

45 Coffee, J.C.: Liquidity Versus Control: The Institutional Investor As Corporate Monitor, Columbia Law Review, 91 1991, pp. 1310-1318

46 Bainbridge, S.M.: Corporate Governance after the Financial Crisis, Oxford, 2012, pp. 240- 245; Wachter, BW.: The Case Against Shareholder Empowerment, University of Pennsylvania Law Review, 158 2009, p. 653
} 
The parallel implication of free-riding though further impedes the fruition of collective action. If a number of shareholders will choose not to engage in the collective action, ${ }^{47}$ they may still enjoy the fraction of all advantages produced by that collective action should it is initiated. ${ }^{48}$ The costs of intervention can be incurred by the participants in the collective action, but the benefit will still be shared, even at a smaller fraction. Thus, a shareholder may find free-riding an advantageous alternative than participation. ${ }^{49}$ But should a collective action arises, free-riding acts to the detriment of shareholders participating in the collective action because of the provision of fewer advantages to them as a result of incurring more costs, thus making it costlier to be engaged. ${ }^{50}$ Since shareholders under this logic will engage only when the advantage is significant enough to outweigh the costs, the element of free riding can significantly impede the extent collective action will be undertaken, as it can influence shareholders not to engage given the growing number of costs and the minimised advantage conferred to them. ${ }^{51}$

The traditional logic of collective action correctly identifies several material problems in establishing shareholder collective action. This includes the material issue of costs, free-riding and the limited incentives in engaging in such an action in the absence of a significant advantage. However, the traditional logic of collective action does not entirely resonate with all material considerations in need to be taken when considering collective action in the corporate context. Firstly, collective action can be as beneficial as any other alternative course of action in terms of choices available to each individual in a group. ${ }^{52}$ This is because the only way an individual can get any advantage or most of the advantage conferred from a collective action will be to refrain from free-riding or not participating at all. ${ }^{53}$ In the corporate context then, shareholders will have to consider whether collective action is advantageous enough in comparison with alternative courses of action.

Secondly, the extent of latency for shareholders in the corporate context does not depend much on the number of shareholders, but on the degree of concen-

\footnotetext{
47 Moore, Petrin (n 30), p. 118

48 Grossman, S.J.; Hart, O.J.: Takeover Bids, The Free-Rider Problem, And The Theory Of The Corporation, The Bell Journal of Economics, 11 1980, p. 42

49 Rock (n 38) pp. 454; 461

50 ibid

51 Schelling, T.C.: Micromotives And Macrobehaviour, New York, 1978, pp. 213-243

52 Hirschman, A.O.: Shifting Involvements: Private Interest And Public Action, Princeton, 1982, pp. $77-82$

53 ibid
} 
tration of shareholding ownership. ${ }^{54}$ Latency then for a shareholder collective action depends on the smallest efficacious group of shareholders that has the incentives and voting power to engage in a collective action. The smallest efficacious group is based on the degree of concentration of shareholding ownership and the extent shareholder voting power and influence of the efficacious group can be sufficient in engaging in a collective action. ${ }^{55}$ This means that the larger the concentration is in a company, the easier the smallest efficacious group can be found to engage in a collective action. ${ }^{56}$ If the advantage from a collective action to keep the management accountable will not be provided unless the full costs of engagement are being paid; and provided that each shareholder holds information about the number of shareholders that can form an efficacious group to undertake that collective action; an effective efficacious group can be created to hold such collective action as a means to provide the advantage to the whole of the group. ${ }^{57}$

Because of this, a shareholder must decide the best course of action for itself based on the information the shareholder holds about the existence of an efficacious group capable of undertaking that very collective action effectively to confer the advantage to shareholders. ${ }^{58}$ Should the information indicates that an advantage is capable of being conferrable to shareholders, the choice for shareholders to engage in a collective action becomes a matter of the best course of action available compared to alternative courses of action. Free riding for example will affect shareholder collective action only when the free-riding behaviour will disable the ease or the ability to form an efficacious group. ${ }^{59}$ If high concentration though renders collective action feasible, free-riding becomes less favourable, as the probability of not getting any advantage is increasing with the increase in probability of not forming an efficacious group, since its abstention will increase the possibility of rendering collective action unachievable and the shareholder not getting any advantage. ${ }^{60}$ The same applies to considerations regarding exiting the company. ${ }^{61}$ If other

\footnotetext{
54 Hardin, R.: Collective Action, Baltimore, 1983, pp. 25-26

55 Rasmussen, E.: Games And Information: An Introduction To Game Theory, Oxford, 1981, pp. $43-53$

56 ibid

57 Rock (n 38) p. 458

58 ibid

$59 \quad$ Ibid p. 460

60 Hirschman, A.: Exit, Voice, And Loyalty: Responses To Decline In Firms, Organizations, And States, London, 1970, Chapters 2 and 3

${ }^{61}$ Rock (n 38) p. 461
} 
factors do not contribute to render exiting the company a feasible option; ${ }^{62}$ the provision of the advantage from the collective action for each individual shareholder increases with the rate of concentration of the company. ${ }^{63}$ Shareholders then will engage in a collective action even when the advantage provided is actually zero, to the extent the rest of the alternative courses of action are not more beneficial than engagement in a collective action.

Thirdly, shareholders tend to be incentivised by other axioms to those of self-interest and economic rationality as well. ${ }^{64}$ In trying to explain how latent groups can still engage in a collective action, Olson identified that individuals may be compelled to engage in a collective action to mitigate any further losses in advantages; ${ }^{65}$ or possess selective incentives arising from potential advantages privately to each individual should a collective action is undertaken. ${ }^{66}$ In addition to these, other axioms may incentivise shareholders to engage in a collective action. ${ }^{67}$ Such axioms include convention arising from the frequent exercise of shareholder rights; ${ }^{68}$ incentives with regards to fairness and responsibility to correct corporate wrongs to this extent; ${ }^{69}$ economically extrarational behaviour that drives them into such an engagement, ${ }^{70}$ such as actions accruing from moralistic pursuits, ${ }^{71}$ sentiment arising from the shareholders' relationship and attachment to the company; ${ }^{72}$ and the idea of social responsibility as a means to correct corporate wrongs affecting the society in general. ${ }^{73}$

These axioms are capable of further bolstering the feasibility of shareholders engaging in a collective action. If a collective action is undertaken from shareholders that have different axioms, shareholders can keep the management accountable as a by-product of the relative incentives to contribute into a col-

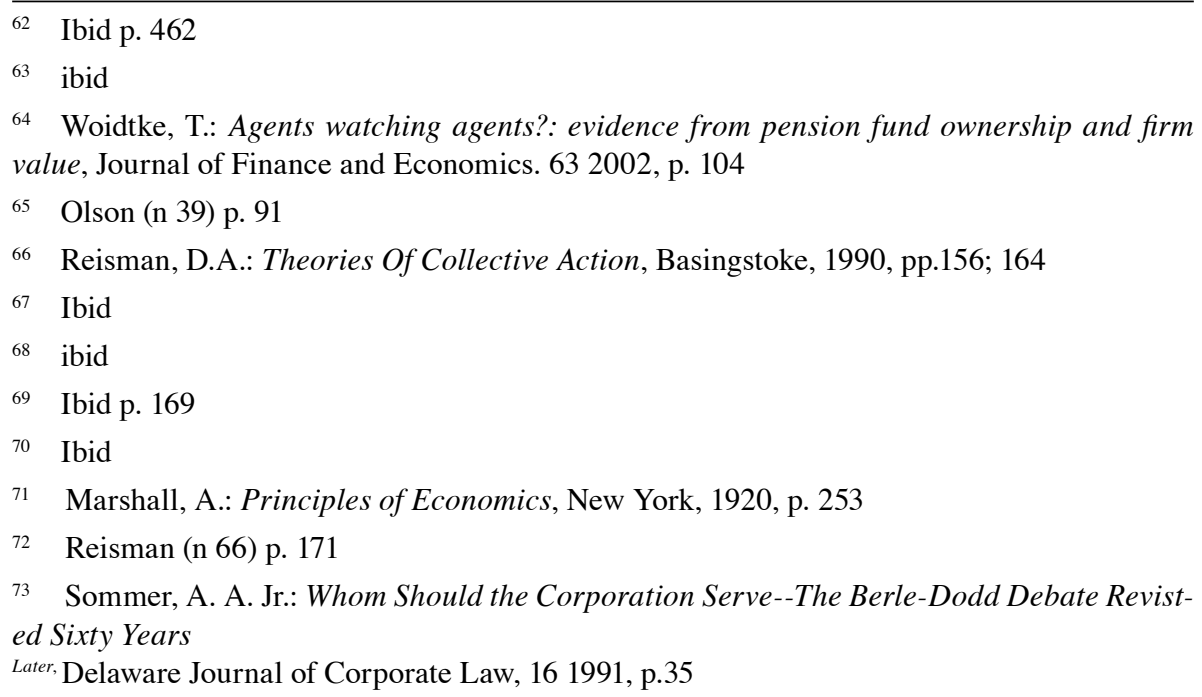


lective action. ${ }^{74}$ Based on the level of concentration of shareholding ownership and the availability of information, shareholders have the ability to convert or utilise their power based on their incentives to keep the management accountable as a means to gain their desired advantage that managerial accountability will provide it. ${ }^{75}$ Thus, if a shareholder or an efficacious group determines that it may be irrational for shareholders to engage in a collective action because of the limited availability of an advantage or the collective action stands as less advantageous from other alternative courses of action; shareholders may determine rational to organise shareholders incentivised from different axioms to ensure that the advantage is to be provided through the common goal of achieving managerial accountability. ${ }^{76}$

Therefore, subject to the existence of other axioms that may require accountability by shareholders important, shareholders will engage in a collective action if concentration in shareholding ownership will allow shareholders gaining an advantage high enough in comparison to any alternative courses of action. At this point, it must be noted that several parameters determine the extent shareholder collective action is a feasible option to shareholders. The first of the parameters concern the amount of costs. The 2017 Directive has made its efforts to alleviate costs through the introduction of rules for non-discrimination in costs between national and cross-border exercise of shareholder rights. The introduction of these rules will definitely assist in the encouragement of shareholders exercising their rights more frequently, especially at a cross-border level. ${ }^{77}$ In addition, the transparency laws introduced by the Directive will further mitigate costs and thus contribute to better engagement. ${ }^{78}$ Nevertheless, internal agency costs vary to a significant extent from company to company and depends much on the action in need to be taken and the company's internal controls. ${ }^{79}$ This is because, active shareholder participation requires the assessment and adoption of a number of strategies, in addition to the need to align such strategies with the various shareholder interests to minimise the

\footnotetext{
74 Fama, E. F.: Agency Problems And The Theory Of The Firm, Journal of Political Economy, 88 1980, pp. 292-295

75 ibid

76 Hardin (n 54) p. 31

77 Belcredi, M.; Ferrarini, G.: Corporate boards, incentive pay and shareholder activism in Europe: main issues and policy perspectives in Belcredi, M.; Ferrarini, G. (eds): Boards and Shareholders in European Listed Companies: Facts, Context and Post-Crisis Reforms, Cambridge, 2013, p.13

78 Berglöf, E.:Reforming Corporate Governance: Redirecting the European Agenda, Economic Policy, 12 1997, p. 91

79 Katelouzou, D.: Myths And Realities Of Hedge Fund Activism: Some Empirical Evidence, Virginia Law \& Business Review, 7 2013, p.578
} 
risk of failure. ${ }^{80}$ Such costs can be further mitigated if shareholders are more readily encouraged to use electronic means to exercise their rights or assess the likeliness of engaging in a collective action. While European corporate law has encouraged the introduction of electronic voting for shareholders as a means to alleviate further the costs of participation, ${ }^{81}$ the rigorous and active encouragement of shareholders to use electronic means or the better administration of the disclosure of information using online public records will assist in further mitigating costs.

The second parameter is the information available to shareholders. If the information about the efficacious group capable of undertaking the collective action is enough for a shareholder to consider that it is needed to engage in collective action, a shareholder will require to use that information and assess the viability of engaging in such an action. Similarly, the engagement of a collective action much relies not only on the information each shareholder has for each shareholder, but also on information related to the company as well, which is subject to managerial control. ${ }^{82}$ The 2017 Directive's rules on the disclosure of information and the achievement of transparency by disclosing the shareholder engagement policy publicly will materially contribute to easier access to information, which will assist in more active shareholder participation. Notwithstanding, the quality of information remains an issue. While the transmission of such information will readily make shareholders capable of engaging in a collective action to keep the management accountable more effectively, the extent they will engage in such an action relies much not only on the quantity and accessibility of information, but also on its quality. If the information submitted bears practical inaccuracies, shareholders may find themselves not only in a difficult position to engage in a collective action regardless of the availability of information, but also find themselves as poor accountability monitors for corporate governance. ${ }^{83}$ Though corporate information quality has gone up over the recent years, ${ }^{84}$ the need for ensuring the standard of quality remains of paramount importance as well.

\footnotetext{
${ }^{80}$ Gilson, R.J.; Gordon, J.N.: The Agency Costs Of Agency Capitalism: Activist Investors And The Revaluation Of Governance Rights, Columbia Law Review, 113 2013, p. 874

81 Shareholder Rights Directive 2007 (as amended by the Shareholder Rights Directive 2017), Art. 8

82 Galbraith, J.K.: The new industrial state (Reprint), Princeton, 2007, p.96

83 Berglöf, E.;Pajuste, A.: What Do Firms Disclose and Why? Enforcing Corporate Governance and Transparency in Central and Eastern Europe, EFA 2005 Moscow Meeting, 2005, pp. $9-11$

84 Vincke, F., Heimann, F. (ed.): Fighting corruption A Corporate Practices Manual, ICC, 2003, p. 135
} 
The final parameter lies in the introduction of shareholder intermediaries and the rise of institutional shareholders. This is because the effective exercise of shareholder rights now relies much on the extent asset managers of institutional shareholders or other intermediaries will have the incentives to use the information available to exercise their shareholder rights effectively. ${ }^{85}$ To many asset managers of private funds or hedge funds or other shareholder intermediaries, the exercise of shareholder rights must be cost-effective to be rendered as a feasible solution for them in terms of their engagement; or selective incentives must require their exercise important. ${ }^{86}$ The existence of alternative courses of action though may be regarded more beneficial to them. ${ }^{87}$ Regardless of the fact that collective action will provide an advantage to shareholders that can be more beneficial than alternative courses of action, institutional shareholders typically hold diversified portfolios of shareholding in various companies as a means of ensuring the beneficiaries' interests. ${ }^{88}$

Asset managers however, because of this diversification, may not consider engagement in the collective action of a company beneficial, irrespective of the fact that the exercise of shareholder rights can provide advantages that are in the best interests of such beneficiaries should the action is successful. ${ }^{89}$ The reason behind this rests on the fact that asset managers typically act based on the information they hold to make their portfolio more competitive or attractive for their current and future beneficiaries. Asset managers then may be concerned to use the information to engage in alternative courses of action to ensure that current beneficiaries' funds are maintained instead of exercising shareholder rights and engage in a collective action, which bears a sufficient element of risk of failure..$^{0}$ This means though that asset managers may be more predominantly concerned with the advancement of the competitiveness of their portfolio instead of them conferring accountability in the investee company. ${ }^{91}$ The same applies to shareholders that are not incentivised primarily from profit, such as pension funds and/or other groups holding shares or in-

\footnotetext{
85 Gilson, R.J.; Gordon, J.N.: 'Agency Capitalism: Further implications of equity intermediation' in Hill, J.G. and Thomas, R.S. (eds.): Research Handbook on Shareholder Power, Cheltenham, 2015; p. 42

86 ibid

87 ibid

88 ibid

89 ibid

90 Kahan, M.; Rock. E.B.; Hedge Funds in Corporate Governance and Corporate Control, University of Pennsylvania. Law Review, 155 2007, pp. 1070-1075

91 Gilson, Gordon (n 85) pp. 39-43
} 
dividual shareholders, ${ }^{92}$ as they may face the same disincentives as asset managers in private equity funds and hedge funds. ${ }^{93}$ To the extent fiduciary duties do not apply to the manager of such funds that render participation important or mandatory, ${ }^{94}$ managers of such groups or individuals may be reluctant to undertake an engagement in a collective action, especially if funding for such intervention is minimal or if the management is closely tied with the company and/or its beneficiary groups. ${ }^{95}$ Free-riding therefore, because of the existence of such intermediaries and their incentives can surface as a result of a possible abstention from the collective action, that can impede the development of an efficacious group to undertake the collective action and thus the conferring of any advantage at all to shareholders or the provision of accountability.

An effective corporate governance model therefore requires the consideration of two key factors to counter intermediary disincentives to exercise shareholder rights. ${ }^{96}$ The first is the encouragement of shareholders to exercise their rights to keep the management accountable. The encouragement of shareholders exercising their rights can have its basis on facilitating more power and influence within the corporate structure to monitor the management effectively. This is something that the Directive provides to some extent through the introduction of voting on the remuneration policy and the approval of material related-party transactions. Both powers can surely contribute to the facilitation of more active engagement and greater accountability. The voting on the remuneration policy gives the ability to shareholders to raise their concerns about excesses in remuneration when such remuneration does not crystallize corporate performance. ${ }^{97}$ Similarly, the voting on related-party transactions will give shareholders the ability to take an advisory role in the affairs of the company, especially when there are significant changes in its construction, thus rendering them an adequate voice in bringing changes to the company for its sustainable growth. ${ }^{98}$

\footnotetext{
92 ibid

93 Gilson, Gordon (n 80) p. 874

94 Mccormack, G.: Sexy but not sleazy: trustee investments and ethical considerations (United Kingdom), The Company Lawyer, 19(2) 1998, p. 40

95 Thomas, R.S.: Realigning Corporate Governance: Shareholder Activism by Labor Unions, Cornell Law Faculty Publications. Paper 530, available at http://scholarship.law.cornell.edu/ facpub/530

96 Chiu, I.; Katelouzou; D.: From Shareholder Stewardship to Shareholder Duties: Is the Time Ripe?, Nordic \& European Company Law LSN Research Paper Series no 18-10, 2017, p. 143

97 Thomas, R.S.: Say on Pay Around the World, Washington University Law Review, 92 2015, p.711

98 Roth, M.: Related Party Transactions, 2016, Available at SSRN at http://dx.doi.org/10.2139/ Ssrn. 2710128
} 
Despite their significance, both powers can be subject to a number of implications that may tamper their usefulness or effectiveness. The use of voting on the remuneration policy may be of limited use to shareholders in Continental Europe where shareholders hold enough concentration and can thus keep the management accountable without relying on their remuneration to exert discipline. ${ }^{99}$ Nevertheless, if shareholder dispersion in Continental Europe continues to disperse because of the continuing convergence of ideals and the internationalization of equity capital markets, the voting on remuneration policy can become an adequate tool in shareholders upholding accountability. ${ }^{100}$ On the same premise, the approval of related-party transactions much depend on the definition of related-party transactions; the boundaries each Member State has on such related-party transactions; and the extent such transactions are determined to be either subject to approval or falling within self-dealing. ${ }^{101}$ Even if these implications do not stand as an impediment of shareholders taking an adequate vote on such matters, national legal barriers which may preclude either intra-shareholder communication. Similarly, the agenda setting of the general meeting for such voting becomes subject to national law regulation, which may not provide ample time for shareholder to reflect on the matters available for them effectively. ${ }^{102}$ Such barriers however can hinder substantially the extent these rights are to be exercised efficiently, thus discouraging active shareholder engagement. A legal framework that assists further in the facilitation of active voice apart from the provision of such powers becomes mandatory as well for the facilitation of such model by European company law.

The second factor is the establishment of requiring the exercise or engagement of shareholder rights. Such a duty has been introduced over the years in several jurisdictions in the EU on a voluntary basis through the introduction of national soft-law of stewardship that define asset managers' responsibilities. ${ }^{103}$ The creation of a soft law notion of stewardship though may not be enough in compelling shareholders to engage in keeping the management accountable

99 Milbourn, T.T.: Financial Systems and Corporate Governance, Journal of Institutional \& Theoretical Economics, 154 1998, p. 174

100 Bratton, W.W.; McCahery, J.A.: Comparative Corporate Governance and the Theory of the Firm: The Case Against Global Cross Reference, Columbia Journal of Transnational Law, 38 1999, p.234

101 Moscariello, N.: Related Party Transactions in Continental European Countries: Evidence from Italy, International Journal of Disclosure and Governance, 2011, p. 130

102 Masouros, P. E.: Is the EU Taking Shareholder Rights Seriously? An Essay on the Impotence of Shareholdership in Corporate Europe, European Company Law, 7 2010, p.200

103 Financial Reporting Council (FRC), The UK Stewardship Code 2010, 2012, see https:// www.frc.org.uk/Our-Work/Codes-Standards/Corporate-governance/UK-Stewardship-Code. aspx. 
effectively. ${ }^{104}$ This is because, in the absence of hard-law compelling shareholders to exercise their rights, shareholders may as well provide justification for not exercising such rights. As such, stewardship soft-laws may stand unable to change many of institutional shareholders' current practices or induce them to be more active participants in corporate governance. ${ }^{105}$

On the same premise, the 2017 Directive requires shareholder engagement through the requirement of exercising shareholder rights and the disclosure of shareholder engagement policy and its exercise on a comply-or-explain basis. ${ }^{106}$ Though it seems that the 2017 Directive's introduction of law will bear the same issues as national stewardship laws so far, Katelouzou and Chiu argue that the difference of the now 2017 Directive lies in the expectation from shareholders to at least engage with the exercise of shareholder rights. ${ }^{107}$ If an institutional shareholder chooses not to exercise its rights and provide an explanation to this extent, the Directive's introduction of laws will assume at least a duty of engagement with the company's corporate governance or the exercise of shareholder rights based on the requirement of the disclosure of the engagement policy and the means such policy is exercised. ${ }^{108}$ While this is a significant step towards the facilitation of the model of seeing shareholders as a credible accountability body, the introduction of an explicit duty for shareholders to exercise their rights could have introduced more active shareholder participation. Nevertheless, the introduction of such a duty requires the careful consideration of a number of related issues, both at a national and European level. Such issues include the consideration of the legal interpretation of shareholder fiduciary duties at a national level, the extent the introduction of such duties conform with the practices and realities of each national corporate legal system, the basis on which shareholders should exercise their rights and the purpose of exercising such rights and the position of shareholders in the company.

\section{THE BASIS OF EXERCISING SHAREHOLDER RIGHTS}

One of the key factors that determine materially the effectiveness of shareholder power as an accountability mechanism is the extent shareholder rights will

104 Cheffins, B.R., The Stewardship Code's Achilles' Heel, University of Cambridge Faculty of Law Research Paper No. 28/2011, 2011, p. 17

105 ibid

106 Chiu, Katelouzou (n 96), p. 144

107 ibid

108 ibid p.145 
actually be exercised to confer accountability to the company for its sustainable growth. ${ }^{109}$ This is because of the possible abuse of power by shareholders to secure short-term profits. ${ }^{110}$ As shareholder rights are costly to be exercised, shareholders may seek short-term returns to cover the costs of exercising their rights and accumulate as much returns as possible, irrespective of the fact that such course of action will be to the detriment of the company. ${ }^{111}$ Shareholder rights then can be used to exercise accountability not for the company's best functioning and performance, but for the security of more returns to its shareholders through the exercise of their rights. Such behavior though may worsen because of the limited investment horizon of shareholders in modern companies. ${ }^{112}$ As many shareholders now hold their shares for a limited amount of time, a number of shareholders may exercise their rights to secure more profits prior to their departure from the company. ${ }^{113}$ This resonates with another impediment of agency capitalism. Asset managers are prone to using shareholder power to secure more residual returns that will confer better returns for their beneficiaries; or increase share market value as a means of advancing the portfolio's competitiveness in the equity capital market. ${ }^{114}$ Similarly, shareholder intermediaries may follow shareholder demands or choose the best course of action for the interests of shareholder, which may not entail achieving accountability in corporate governance. ${ }^{115}$

The extent then shareholder power can be used as an accountability mechanism is contested by the very fact that shareholder power can be used for adverse purposes as well. ${ }^{116}$ Though shareholders have the capability to confer accountability in corporate governance should their agency problems are alleviated, they can as well compel the board to undertake myopic actions to

\footnotetext{
109 ibid

110 Bebchuk, L.: The Myth that Insulating Boards Serves Long-Term Value, Columbia Law Review, 113 2013, p.1658

111 Easterbrook, F.H.; Fischel, D.R.; Voting in Corporate Law, Journal of Law \& Economics, 261983 , p.403

112 ibid

113 Lipton, M.; Savitt, W.; The Many Myths of Lucian Bebchuk, Virginia Law Review, 93 2007, p.746

114 Black, B.S.: Agents Watching Agents: The Promise of Institutional Investor Voice, UCLA Law Review, 39 1992, p. 835; Hazen, T.L.: The Short-Term/Long-Term Dichotomy and Investment Theory: Implications for Securities Market Regulation and for Corporate Law, North Carolina Law Review, 70 1991, p. 140

115 Anabtawi, I.: Some Skepticism About Increasing Shareholder Power, UCLA Law Review, 532006 , p.561

116 Bainbridge (n 46) p.234; Anabtawi, I.; Stout, L.: Fiduciary Duties for Activist Shareholders Stanford Law Review, 60 2008, p. 1291
} 
secure short-term profits; with catastrophic consequences for the company. ${ }^{117}$ This is bolstered by the fact that the capital market's inevitable short-termism influences shareholders to have short-term horizons in each company, and as such penalize directors should they undertake a corporate policy that does not crystallize on share value. ${ }^{118}$ This means though that accountability in corporate governance through the exercise of shareholder power can become a secondary obligation for shareholders, if it can be an obligation at all.

EU company law then requires the establishment of a corporate objective upon which shareholders will exercise their rights to adequately confer accountability for advancing corporate performance and sustainability. The 2017 Directive acknowledges this and seeks to provide a solution by requiring asset managers to disclose in their engagement policy how their policy will contribute to the medium to long-term performance of their assets, which will include the evaluation of the medium to long-term financial and non-financial performance of the company. Through this orientation, the Directive seeks to provide a benchmark for an optimal behavior for shareholders when exercising their rights. By calling shareholders to engage in corporate governance with a medium to long-term orientation of asset performance which will include medium to long-term financial and non-financial corporate performance, the Directive attempts to set a standard for the exercise of shareholder rights by requiring the consideration of the performance of shareholding assets, which can regard corporate performance as a means of regarding public interest objectives as well. ${ }^{119}$

The extent this orientation will contribute to mitigating short-termism though is contestable. The medium to long-term orientation of the pursuit of shareholder power based on asset performance seems to conform with an international set of thinking that shareholder power can contribute to the advancement of the share's long-term value. ${ }^{120}$ This orientation has its basis on the principle of shareholder primacy, which set share value and its wealth maximization as the prime determinants of the medium to long-term performance of the shareholders' assets. ${ }^{121}$ These metrics however cannot ensure that good governance

117 Anderson, R.: The Long and Short of Corporate Governance, Georgetown Mason Law Review, 23 2015), p. 29

118 Grossman, N.: Turning a Short-Term Fling into a Long-Term Commitment: Board Duties in A New Era, University of Michigan Journal of Legal Reform, 43 2010, pp. 923-31

119 Chiu, Katelouzou (n 96), p. 146

120 Bebchuck (n 27) p. 892

121 On the rise of shareholder primacy see Friedman, M.: The Social Responsibility of Business Is to Increase Its Profits, New York Times Magazine, 13 September 1970; Jensen, M.C.; Meckling, W.C.: Theory of the firm: Managerial behavior, agency costs and ownership struc- 
practices are adopted, irrespective of the medium to long-term orientation. ${ }^{122}$

Firstly, the medium to long-term orientation on asset performance seems to lie partly on the rationale that asset performance based on the share's value in the capital market is indicative of the company's performance, ${ }^{123}$ since the capital market is stated to be efficient enough to determine such good or bad governance practices because of changes in share value. ${ }^{124}$ Behavioral economics studies though show that investor biases, such as short-term overvaluation as medium to long-term value, ${ }^{125}$ or acknowledging increases of a company's value as indicative of medium to long-term sustainable development, ${ }^{126}$ render shareholders unable to configure whether good governance practices are adopted based on value so as to exercise their rights to confer accountability based on it. ${ }^{127}$ This is because the extent shareholders choose between shortterm or medium to long-term asset performance based on value can be dubious; as both estimates tend to cancel each other out. For short-term value to differ significantly from medium to long-term value so as for shareholders to pursue the latter based on the Directive's wording and rationale, there is a need for a capital market that is efficient enough so as to indicate that the shareholders' exercise of rights to accumulate short-term profit will confer substantially greater returns than the price of long-term share value. ${ }^{128}$ The abovementioned biases however; and shareholders' possible inclinations for short-term returns because of these biases; may be offset by what is determined to be long-term value of the company, thus making the difference between the two limited and incapable of showing good governance practices. ${ }^{129}$ To add to that, the information available must be of such quality that must crystallize great devia-

\footnotetext{
ture, Journal of Financial Economics, 3 (1976), p. 312. On the convergence of corporate goverance systems on shareholder primacy Hansmann, H.; Kraakman, K: The end of history for corporate law, Georgetown Law Journal, 89(2) 2001, p. 439.

Jansson, A.: No Exit!: The Logic of Defensive Shareholder Activism, Corporate Board: Role, Duties \& Composition, 10 (2014), pp. 16-17; Romano, R.: Less is More: Making Institutional Investor Activism A Valuable Mechanism of Corporate Governance, Yale Journal of Regulation, 18 2001, pp. 222-240

122 ibid

${ }_{123}$ Moore, Petrin (n 30) p. 119

124 Martin, R.: Fixing the Game: Bubbles, Crashes, and What Capitalism Can Learn from the NFL, Boston, 2011, pp. 12-13;

125 Moore, Petrin (n 30) p.121

126 Stout, L.A.: The Shareholder Value Myth, Oakland, 2013, pp. 63-64

127 Moore, Petrin (n 30) p.120

128 Anderson (n 117) pp. 30-41

129 ibid
} 
tion between the company's actual value to determine short-term or long-term value. Nevertheless, several issues related to the quality of information, such as inaccuracies on the value of the share or accounting frauds may tamper the extent short-term or medium to long-term value will differ or the extent the pursuit of either value will lead to the deterioration or the advancement of governance practices within the company. ${ }^{130}$

Such asymmetry then in configuring short-term and medium to long-term value cannot not configure the extent shareholder power will advance corporate governance practices to uphold accountability based on asset performance. ${ }^{131}$ The share value does not relatively make shareholders to keep the management accountable for the company's performance or to uphold good governance practices, but compels them to act based on what is expected in terms of value to them on the belief that value is representative of such performance or good governance practices. ${ }^{132}$ Given however that the difference between what is considered short-term or medium to long-term value will be often thin; and the fact that information provided in the market bears the possibility to be inaccurate; shareholder power exercised on an objective based on value performance may not achieve the responsibility required by the Directive in exercising shareholder rights responsibly to confer accountability, as the corporate objective shareholder power is sought to be exercised primarily sees towards the share's best expectation of value performance rather than correcting actual governance practices.

Secondly, the medium to long-term orientation on asset performance adopted by the 2017 Directive disregards the implications of considering asset performance through maximizing returns as a metric of accountability. ${ }^{133}$ It is undoubted that the medium to long-term approach seeks to crystallize the need of conferring accountability to achieve more residual returns without impeding the interests of stakeholders. ${ }^{134}$ But if the difference between short-term and medium to long-term value is difficult to be identified and thus incapable of determining good governance practices, the introduction of the medium to long-term orientation on enhancing asset performance by maximizing returns

130 Joerg, P. et al.: The Purpose of the Corporation : Shareholder value Maximization?, European Corporate Governance Institute Finance Working Paper No. 95/2005, 2006, p. 13

131 Quiggen, J.: Zombie Economics: How Dead Ideas Still Walk among Us, Princeton, 2010

132 Martin (n 124) pp. 12, 21, 23, 193

133 Anderson (n 117) pp. 40

134 Harper Ho, V.: Enlightened Shareholder Value: Corporate Governance Beyond the Shareholder-Stakeholder Divide, Journal of Corporate Law, 36 2010, p.62. This is also a theme adopted in UK company law under s.172 of the Companies Act 2006. See Keay, A.: The Enlightened Shareholder Value Principle and Corporate Governance, Abingdon, 2012, p.70 
is equally not helpful. Since shareholder incentives and the investment horizon for each shareholder differ, a shareholder's pursuit of a medium to long-term maximization of wealth to enhance asset performance accordingly depends on such incentives and investment horizon, regardless of the Directive's legislative text. ${ }^{135}$ Thus, the medium to long-term orientation in exercising shareholder rights becomes a rather relative term for each shareholder, thus making again the difference of long-term or short-term rather thin. As with value orientation, the exercise of shareholder rights to ensure wealth maximization to improve asset performance bear the risk of adopting practices that may not ensure the company's sustainability or its controlled sustainable growth. If shareholder rights are exercised to keep the management accountable for maximizing wealth in the long-term as per the Directive's wording, accountability will be conferred for securing such wealth maximization that is expected to be longterm performance of assets from the shareholder's own end, which is subject to its investment horizon and their incentives when exercising their rights. ${ }^{136}$ Given however that the difference of long-term and short-term maximization of returns is a dubious metric because of its relativity; an orientation of exercising shareholder rights based on asset performance through maximizing wealth does not assist in any meaningful way in configuring whether good governance practices are actually adopted through the exercise of shareholder rights.

The foregoing arguments resonate with another impediment of placing an orientation based on asset performance as a primary concern for shareholders. Even if the orientation of such asset performance is in the medium to the longterm, the primary focus of exercising shareholder power based on it is capable of inducing shareholders in engaging in activities that do not regard good governance practices, irrespective of the fact that financial or non-financial performance of the company is stated to be included as an assessment consideration. If shareholders are incentivized by their own self-interest and calculative rationality, then the pursuit of shareholder power for profit may lead to short-term activities if the basis on which shareholders will exercise their rights depends on either value or return maximization, which stand incapable of considering good governance practices. At the same time though, it must be noted that shareholders driven by the same axioms or incentivized by other axioms can as well exercise their rights even if the advantage conferred to them is zero, as they may seek good governance practices or determine that alternative courses of action are of no assistance. ${ }^{137}$

135 Stout (n 126) p. 70;

136 Bainbridge (n 46) p. 234

137 Stout, L: Cultivating Conscience: How Good Laws Make Good People, Princeton, 2011, pp. 98 
This means that the course of action that shareholders may undertake rely much on shareholders' systemic behavior. Like every person, shareholders or its asset managers or other intermediaries are pro-social and responsible individuals, ${ }^{138}$ but they are susceptible to biases that can affect their pro-sociality. ${ }^{139}$ The real deal then for corporate law is to provide shareholders a basis that incentivizes them to act responsibly and use their powers to uphold accountability in corporate governance. The Directive's medium to long-term orientation on asset performance will find difficulty in achieving that. According to Stout, any orientation based on shareholder primacy, and given shareholders' susceptibility to investor biases and informational asymmetries, can incentivize shareholders to determine that optimal corporate governance is adopted only through facilitating greater shareholder returns and the increase of share value. ${ }^{140}$ An orientation as such though does not assist in creating incentives to achieve better accountability; nor encourages pro-social shareholders in exercising their rights for accountability purposes. ${ }^{141}$ If a shareholder wishes to further good corporate governance practices, the exercise of shareholder power to pursuit such practices may be outweighed by the furtherance of achieving accountability based on maximizing shareholder wealth or increase share value. ${ }^{142}$ Having this in mind though, and considering that neither metrics are indicative of good corporate governance practices, shareholder incentives of achieving good governance practices may fail because of their efforts to maximize value instead of actually considering the adoption of good governance practices for the company's sustainable growth.

At this point, it must be acknowledged that the inclusion of considering medium to long-term performance of the company in the engagement policy that will regard non-financial performance of the company as well can provide the incentives to shareholders to regard good governance practices. Though this may be true, the inclusion and consideration of governance practices still exists as a secondary consideration when exercising shareholder rights. The primary obligation of shareholders remains the performance of their assets in the medium to long-term, which assumes the exercise of shareholder rights to enhance its value and confer more residual returns. Given though that both metrics cannot measure good governance practices, the possibility for regarding good governance practices while adopting a pursuit of exercising shareholder rights based on asset performance will be outweighed by the very pursuit of maximizing asset performance itself.

\footnotetext{
138 Stout (n 126) pp. 98

139 ibid

140 ibid

141 ibid

142 Anderson (n 117) p. 58
} 
Following this then, European company law must seek the establishment of a corporate objective for shareholders that does not seek the enhancement of asset performance, but the actual pursuit of good governance practices by shareholders for the company's sustainable growth. If it can be readily agreed that shareholders can successfully keep the management accountable in the sense that they can bring changes to the company should agency problems related to collective action and agency capitalism are alleviated; then the primary basis on which shareholders must pursue their power lies in the adoption of good governance practices for the company's financial and non-financial performance. While the Directive insists on the consideration of asset performance as a metric of good governance, the extent shareholders will contribute to enhancing accountability in corporate governance under it remains thin.

\section{CONCLUSION}

The changes the Directive introduces is definitely a step towards the effective facilitation of a model where shareholder power is used as an accountability mechanism in corporate governance. This is being undertaken through the enhancement of shareholder power, the encouragement of better engagement; the transparency of information; and the alleviation of cross-border costs. Nevertheless, a number of material implications need to be addressed more effectively by European and national corporate law to ensure the model's effectiveness. Firstly, the issues related to the establishment of collective action in the corporate context, such as the availability and quality of information, the incurrence of costs to exercise shareholder rights, the incentives of asset managers to exercise shareholder rights and the element of free-riding can significantly affect the extent shareholders will be able to exercise their rights effectively. Though the Directive deals to some extent with these issues, the possibility of disclosure of inaccurate information, the incurrence of costly engagements for corporate governance and the extent shareholder rights will be exercised by asset managers or shareholder intermediaries requires better regulation and consideration. Similarly, the basis on which shareholder power is sought by the Directive equally needs further consideration. This is because the prime orientation put on shareholders to regard asset performance will not ensure that shareholders will not exercise their rights for short-term purposes; nor will assist them in exercising their rights to confer accountability effectively in corporate governance.

The abovementioned implications lead to considerations on whether shareholders should exercise their rights to influence the control of the company. One however should not forget the merits of having shareholders acting as 
monitors of corporate governance. Shareholders can have the incentives and the power because of their position to make material changes to the company as a means of upholding accountability. Such advancement of accountability can definitely assist in the development of corporate governance regulation, but also in the adoption of appropriate corporate practices that will mitigate the possibility of having further corporate scandals and economic crises. The issue therefore for EU corporate law is not whether it is appropriate to adopt a model where shareholders act as an accountability body; but consider the extent the implications discussed in this Article can be alleviated by corporate law to make such a model effective. The Directive then should not be regarded as a failed attempt to regulate shareholder rights to be exercised for accountability purposes. On the contrary, the 2017 Directive should be regarded as the starting point towards the facilitation of a model where shareholders act as an accountability body. European company law then should take the implications discussed in this paper into account as well to ensure the model's effectiveness.

\section{LITERATURE}

1. Anabtawi, I.: Some Skepticism About Increasing Shareholder Power, UCLA Law Review, 532006.

2. Anabtawi, I.; Stout, L.: Fiduciary Duties for Activist Shareholders Stanford Law Review, 602008.

3. Anderson, R.: The Long and Short of Corporate Governance, Georgetown Mason Law Review, 232015.

4. Armour, J. et al:: Shareholder Primacy and the Trajectory of UK Corporate Governance, British Journal of Industrial Relations, 412003

5. Bainbridge, S. M.: Why a Board? Group Decisionmaking in Corporate Governance, Vanderbilt Law Review, 552002

6. Bainbridge, S.M.: Corporate Governance after the Financial Crisis, Oxford, 2012 - DOI: https://doi.org/10.1093/acprof:oso/9780199772421.001.0001

7. Bava, F.; Devalle, A.: Corporate governance and best practices: the Parmalat case, GSTF Business Review, 22012

8. Bebchuck, L. B.: The Case for Increasing Shareholder Power, Harvard Law Review, 1182005

9. Bebchuk, L.: The Myth that Insulating Boards Serves Long-Term Value, Columbia Law Review, 1132013

10. Belcredi, M.; Ferrarini, G.: Corporate boards, incentive pay and shareholder activism in Europe: main issues and policy perspectives in Belcredi, M.; Ferra- 
rini, G. (eds): Boards and Shareholders in European Listed Companies: Facts, Context and Post-Crisis Reforms, Cambridge, 2013

11. Berglöf, E.:Reforming Corporate Governance: Redirecting the European Agenda, Economic Policy, 121997

- DOI: https://doi.org/10.1111/1468-0327.00017

12. Berglöf, E.;Pajuste, A.: What Do Firms Disclose and Why? Enforcing Corporate Governance and Transparency in Central and Eastern Europe, EFA 2005 Moscow Meeting, 2005

13. Berle A.A; Means, G.G.: The Modern Corporation and Private Property, revised ed., New Jersey, 1991

14. Black, B.S.: Agents Watching Agents: The Promise of Institutional Investor Voice, UCLA Law Review, 391992

15. Black, B.S.: Shareholder Passivity Re-examined, Michigan Law Review, 891990

16. Bratton, W.W.; McCahery, J.A.: Comparative Corporate Governance and the Theory of the Firm: The Case Against Global Cross Reference, Columbia Journal of Transnational Law, 381999

17. Cheffins, B. R.: Law as Bedrock: The Foundations of an Economy Dominated by Widely Held Public Companies, Oxford Journal of Legal Studies, 232003

- DOI: https://doi.org/10.1093/ojls/23.1.1

18. Cheffins, B.R., The Stewardship Code's Achilles' Heel, University of Cambridge Faculty of Law Research Paper No. 28/2011, 2011

19. Chiu, I.; Katelouzou; D.: From Shareholder Stewardship to Shareholder Duties: Is the Time Ripe?, Nordic \& European Company Law LSN Research Paper Series no $18-10,2017$, p. 143

20. Coffee, J.C.: Liquidity Versus Control: The Institutional Investor As Corporate Monitor, Columbia Law Review, 911991

- DOI: https://doi.org/10.2307/1123064

21. Communication From The Commission To The European Parliament, The Council, The European Economic And Social Committee And The Committee Of The Regions: Action Plan: European company law and corporate governance - a modern legal framework for more engaged shareholders and sustainable companies (COM/2012/0740, 2012)

22. Davies, P.: Shareholders in the United Kingdom in Hill, J.G. and Thomas, R.S. (eds.): Research Handbook on Shareholder Power, Cheltenham, 2015

- DOI: https://doi.org/10.4337/9781782546856.00033

23. Dodd E. M.: For whom are corporate managers trustees, Harvard Law Review, 45 1932,

24. du Plessis, J. et al.: German Corporate Governance in International and European Context (2nd edn), Berlin, 2012 
25. Easterbrook, F.H.; Fischel, D.R.; Voting in Corporate Law, Journal of Law \& Economics, 261983

- DOI: https://doi.org/10.1086/467043

26. Eriksson, K.: Corporate Governance in the European Union post-Enron, Business Law Review, 152003

27. Fama, E. F.: Agency Problems And The Theory Of The Firm, Journal of Political Economy, 881980

- DOI: https://doi.org/10.1086/260866

28. Fama, E.F.; Jensen, M.C.: Separation of Ownership and Control, Journal of Law and Economics, 261983

- DOI: https://doi.org/10.1086/467037

29. Fama, E.G.; Jensen, M.C.; Agency Problems and Residual Claims, The Journal of Law \& Economics, 26 (2) 1983

- DOI: https://doi.org/10.1086/467038

30. Fox, L.: Enron: Rise and Fall, Hoboken, 2003;

31. Friedman, M.: The Social Responsibility of Business Is to Increase Its Profits, New York Times Magazine, 13 September 1970

32. Galbraith, J.K.: The new industrial state (Reprint), Princeton, 2007

33. Gillan, S. L., Starks, L.T.: Corporate Governance Proposals and Shareholder Activism: The Role of Institutional Investors, Journal of Finance and Economics, 572000

34. Gilson, R.J.; Gordon, J.N.: 'Agency Capitalism: Further implications of equity intermediation' in Hill, J.G. and Thomas, R.S. (eds.): Research Handbook on Shareholder Power, Cheltenham, 2015

- DOI: https://doi.org/10.4337/9781782546856.00009

35. Gilson, R.J.; Gordon, J.N.: The Agency Costs Of Agency Capitalism: Activist Investors And The Revaluation Of Governance Rights, Columbia Law Review, 1132013

36. Grossman, N.: Turning a Short-Term Fling into a Long-Term Commitment: Board Duties in A New Era, University of Michigan Journal of Legal Reform, 432010

37. Grossman, S.J.; Hart, O.J.: Takeover Bids, The Free-Rider Problem, And The Theory Of The Corporation, The Bell Journal of Economics, 111980

- DOI: https://doi.org/10.2307/3003400

38. Hansmann, H.; Kraakman, K: The end of history for corporate law, Georgetown Law Journal, 89(2) 2001

39. Hardin, R.: Collective Action, Baltimore, 1983, pp. 25-26

40. Harper Ho, V.: Enlightened Shareholder Value: Corporate Governance Beyond the Shareholder-Stakeholder Divide, Journal of Corporate Law, 362010

- DOI: https://doi.org/10.2139/ssrn.1476116 
41. Hazen, T.L.: The Short-Term/Long-Term Dichotomy and Investment Theory: Implications for Securities Market Regulation and for Corporate Law, North Carolina Law Review, 701991

42. Hill, J.: Visions and Revisions of the Shareholder, The American Journal of Comparative Law, 482000

43. Hirschman, A.: Exit, Voice, And Loyalty: Responses To Decline In Firms, Organizations, And States, London, 1970

44. Hirschman, A.O.: Shifting Involvements: Private Interest And Public Action, Princeton, 1982

45. Jansson, A.: No Exit!: The Logic of Defensive Shareholder Activism, Corporate Board: Role, Duties \& Composition, 10 (2014)

46. Jensen, M.C.; Meckling, W.C.: Theory of the firm: Managerial behavior, agency costs and ownership structure, Journal of Financial Economics, 3 (1976)

- DOI: https://doi.org/10.1016/0304-405X(76)90026-X

47. Joerg, P. et al.: The Purpose of the Corporation : Shareholder value Maximization?, European Corporate Governance Institute Finance Working Paper No. 95/2005, 2006

48. Kahan, M.; Rock. E.B.; Hedge Funds in Corporate Governance and Corporate Control, University of Pennsylvania. Law Review, 1552007

49. Katelouzou, D.: Myths And Realities Of Hedge Fund Activism: Some Empirical Evidence, Virginia Law \& Business Review, 72013

50. Keay, A.: The Corporate Objective, Cheltenham, 2011

- DOI: https://doi.org/10.4337/9780857933126

51. Keay, A.: The Enlightened Shareholder Value Principle and Corporate Governance, Abingdon, 2012

- DOI: https://doi.org/10.4324/9780203104927

52. Lipton, M.; Savitt, W.; The Many Myths of Lucian Bebchuk, Virginia Law Review, 932007

53. Mallin C.: Institutional investors: the vote as a tool of governance, Journal of Management Governance, 162012

- DOI: https://doi.org/10.1007/s10997-010-9137-2

54. Marshall, A.: Principles of Economics, New York, 1920

55. Martin, R.: Fixing the Game: Bubbles, Crashes, and What Capitalism Can Learn from the NFL, Boston, 2011

56. Masouros, P. E.: Is the EU Taking Shareholder Rights Seriously? An Essay on the Impotence of Shareholdership in Corporate Europe, European Company Law, 7 2010 
57. Mccormack, G.: Sexy but not sleazy: trustee investments and ethical considerations (United Kingdom), The Company Lawyer, 19(2) 1998

58. Milbourn, T.T.: Financial Systems and Corporate Governance, Journal of Institutional \& Theoretical Economics, 1541998

59. Moore, M.; Petrin, M.: Corporate Governance: Law, Regulation and Theory, London, 2017

- DOI: https://doi.org/10.1057/978-1-137-40332-2

60. Morck R. (ed): A History of Corporate Governance Around the World: Family Business Groups to Professional Managers, University of Chicago Press, 2007

61. Moscariello, N.: Related Party Transactions in Continental European Countries: Evidence from Italy, International Journal of Disclosure and Governance, 2011

62. Olson, M.: The Logic of Collective Action, London, 1971

63. Parkinson, J.E.: Corporate Power and Responsibility: Issues in the Theory of Company Law, Oxford/ Oxford University Press, 2002;

64. Quiggen, J.: Zombie Economics: How Dead Ideas Still Walk among Us, Princeton, 2010

65. Rasmussen, E.: Games And Information: An Introduction To Game Theory, Oxford, 1981, pp. 43-53

66. Reisman, D.A.: Theories Of Collective Action, Basingstoke, 1990

- DOI: https://doi.org/10.1057/9780230389977

67. Rock, E.B.: The Logic and (Uncertain) Significance of Institutional Shareholder Activism, The Georgetown Law Journal, 791990

68. Romano, R.: Less is More: Making Institutional Investor Activism A Valuable Mechanism of Corporate Governance, Yale Journal of Regulation, 182001

69. Rose, P.: The Corporate Governance Industry, Journal of Corporate Law, 32 2007

70. Roth, M.: Related Party Transactions, 2016.

- DOI: https://doi.org/10.2139/ssrn.2710128

71. Schelling, T.C.: Micromotives And Macrobehaviour, New York, 1978

72. Schulz, M.; Wasmeier, O.: The Law of Business Organizations: A Concise Overview of German Corporate Law, Berlin, 2012

- DOI: https://doi.org/10.1007/978-3-642-17793-4

73. Sharfman, B.S.: Activist Hedge Funds In A World Of Board Independence: Creators Or Destroyers Of Long-Term Value?, Columbia Business Law Review, 2015

74. Sommer, A. A. Jr.: Whom Should the Corporation Serve--The Berle-Dodd Debate Revisted Sixty Years Later, Delaware Journal of Corporate Law, 161991 
75. Stout, L.A.: The Shareholder Value Myth, Oakland, 2013

76. Stout, L: Cultivating Conscience: How Good Laws Make Good People, Princeton, 2011

77. Thomas, R.S.: Realigning Corporate Governance: Shareholder Activism by Labor Unions, Cornell Law Faculty Publications. Paper 530, available at http:// scholarship.law.cornell.edu/facpub/530

78. Thomas, R.S.: Say on Pay Around the World, Washington University Law Review, 922015

79. Vincke, F., Heimann, F. (ed.): Fighting corruption A Corporate Practices Manual, ICC, 2003

80. Wachter, BW.: The Case Against Shareholder Empowerment, University of Pennsylvania Law Review, 1582009

81. Wells, H.: A Long View Of Shareholder Power: From The Antebellum Corporation To The Twenty-First Century, Florida Law Review, 672015

82. Woidtke, T.: Agents watching agents?: evidence from pension fund ownership and firm value, Journal of Finance and Economics. 632002 
